\title{
HUBUNGAN BERPIKIR KRITIS DALAM KEPERAWATAN TERHADAP PASIEN PRASEKOLAH
}

\author{
Atikah Ulfah Marwa
}

ninanamanis@gmail.com

\begin{abstract}
Abstrak
latar belakang : keterampilan berpikir kritis pada mahasiswa keperawatan itu perlu, dengan berpikir kritis mahasiswa tahu apa yang akan ia lakukan selanjutnya, ini juga membantu pasien prasekolah dalam menghadapi hospitalisasi yang mengakibatkan kecemasan. Tujuan : mempelajari sikap berpikir kritis yang kedepannya dapat menemukan jalan keluar. Metode penelitian : literature review dengan cara menganalisis artikel, jurnal maupun text book. Artikel yang digunakan 14 referensi yang diterbitkan sepuluh tahun terakhir yang menggunakan google scholar, google book dan science direct. Hasil : dari hasil literature review dapat disimpulkan, dengan mempelajari berpikir kritis mahasiswa keperawatan dapat mengmukakan pendapat dengan kritis, bila sudah menjadi perawat, dapat menciptakan ide agar pasien prasekolah memimalisir kecemasan dan stress. Kesimpulan : adanya pelajaran berpikir kritis mahasiswa keperawatan mampu memecahkan masalah dengan berdiskusi. Perawat juga dapat membuat pasien terkhusus prasekolah merasa nyaman dengan membahkan ide seperti memberikan permainan terapeutik ataupun membacakan dongeng.
\end{abstract}

Kata kunci: berpikir kritis, hospitalisasi, pasien prasekolah, keperawatan.

\section{Abstract}

background: learning critical thinking in nursing students is necessary, by thinking critically the student knows what he will do next, this also helps preschool patients in carrying out hospitalizations that are trying to cope. Objective: to look for critical thinking that can find a way out. Research methods: literature review by analyzing articles, journals and textbooks. The article used 14 references published over the last ten years using Google Scholar, Google Books and Science Direct. Results: From the results of the literature review it can be concluded, with critical thinking nursing students can express opinions with criticism, if they are already nurses, can create ideas so that preschool patients minimize trying and stress. Conclusion: Students who are critical in learning nursing problems are able to solve problems by discussing. Nurses can also make patients connected comfortably, equipped with good ideas such as providing therapeutic games or reading fairy tales.

Keywords: critical thinking, hospitalization, preschool patients, nursing. 


\section{PENDAHULUAN}

Menurut Halpern

(1996)

berpikir kritis adalah suatu upaya yang dilakukan dalam memberdayakan keterampilan atau strategi kognitif untuk menentukan tujuan yang diharapkan. Oleh karena itu untuk memberikan perawatan yang aman dan efektif bagi pasien dengan kebutuhan yang kompleks sangat penting bagi perawat dapat mengembangkan keterampilan berfikir kritis (Kaddoura, 2010).

Berbagai faktor yang bisa menyebabkan perbedaan dalam mengukur berpikir kritis diantara hasil seseorang yang satu dengan yang lainnya. Menurut American Society of Registered Nurses (2007) adalah dijelaskan berpikir kritis dalam keperawatan sangat dipengaruhi oleh karakter psikologis, fisiologis, serta dapat dipengaruhi oleh lingkungan internal maupun eksternal seperti usia, tingkat kepercayaan, keterampilan, stress, dan kelelahan, serta rekan kerja. Sedangkan hasil penelitian lainnya dikatakan bahwa kemampuan berpikir kritis perawat dalam melaksanakan proses keperawatan tidak dipengaruhi oleh karakteristik individu seperti umur, jenis kelamin, pendidikan, dan pengalaman kerja serta status perkawinan (Sumartini, 2010). Sedangkan dijelaskan oleh lainnya bahwa factor salah satunya yang bisa menurunkan kemampuan berpikir kritis seseorang adalah terjebak dalam rutinitas, dan juga cara tersering yang membuat terjebak dalam rutinitas adalah membiasakan kita menggunakan model kebiasaan berlebihan (Rubenfeld \& Scheffer, 2007). Berpikir kritis juga berpengaruh bagi pasien terkhususnya bagi pasien anak.

$$
\text { Hospitalisasi merupakan }
$$

keadaan dimana seseorang dalam kondisi yang mengharuskan untuk mendapat perawatan dirumah sakit untuk mengatasi atau meringankan sakitnya. Hospitalisasi pada anak dapat menimbulkan kecemasan dan stress dimana hal itu diakibatkan karena adanya perpisahan, kehilangan control, ketakutan mengenai kesakitan pada tubuh, serta nyeri dimana kondisi tersebut belum pernah dialami sebelumnya. Respon fisilogis yang dapat muncul akibat kecemasan yang tidak teratasi yaitu seperti adanya perubahan pada system kardiovaskuler berupa palpitasi, denyut jantung 
meningkat, perubahan pola nafas yang semakin cepat, nafsu makan menurun, gugup, pusing, tremor, hingga insomnia,keluar keringat dingin, wajah menjadi kemerahan, gelisah, rewel, anak mudah terkejut, menangis, berontak, menghindar hingga menarik diri, tidak sabar, tegang, waspada terhadap lingkungan, hospitalisasi juga akan berdampak pada perkembangan anak dimana juga akan mengakibatkan terganggunya proses pengobatan. Perawatan anak yang berkualitas tinggi akan dapat mengurangi kecemasan dan ketakutan yang terjadi karena bila kecemasan dan ketakutan tidak ditangani akan membuat anak menolak tindakan perawatan dan pengobatan yang diberikan sehinngga akan mempengaruhi lamanya perawatan, memperberat kondisi anak bahkan menyebabkan kematian pada anak, dampak dari anak sakit yang tidak ditangani juga akan menyebabkan kesulitan dan kemampuan membaca yang buruk, memiliki gangguan bahasa, menurunnya kemampuan intelektual dan social serta fungsi imun (Saputro, 2017).

Penelitian ini secara umum bertujuan untuk mengetahui hubungan berpikir kritis dalam keperawatan terhadap pasien prasekolah. Rumah Sakit sebagai pemberi layanan kesehatan bertanggung jawab untuk memberikan pelayanan yang bermutu dan aman. Salah satunya perawat, perawat perlu berpikir kritis pula terhadap pasien terkhusus pasien prasekolah.

\section{METODE PENELITIAN}

Metoode penelitian yang digunakan adalah literature review dengan cara menganalisis artikel, jurnal maupun text book yang berkaitan dengan pembelajaran mahasiswa keperawatan belajar berpikir krits untuk membuat keputusan dalam tindakan keperawatan.

Artikel yang digunakan 14 referensi yang diterbitkan sepuluh tahun terakhir yang menggunakan google scholar, google book dan science direct. Dalam mencari artikel, kata kunci yang digunakan ialah hubungan berpikir kritis dalam keperawatan terhadap pasien prasekolah.

\section{HASIL}

Dari pencarian literature, dalam mengurangi kecemasan pada pasien 
prasekolah dapat menggunakan sikap keperawatan, berpikir kritis. Perawat diharapkan memberikan pelayanan yang baik dan profesional salah satunya pasien pra sekolah. Pasien prasekolah pada awalnya memiliki kecemasan saat memasuki rumah sakit karena adanya stresor berupa berpisah dengan keluarga. Perawat dapat menggunakan sikap berpikir kritis agar pasien dan klien meminimalisir kecemasaan diantara keduanya. Juga sebagai mahasiswa keperawatan mampu menguasai sikap berpikir kritis dan profesional sehingga dapat meningkatkan kualitas kesehatan pasien dan menjaga hubungan baik mitra kesehatan maupun pasien dan keluarga pasien.

\section{PEMBAHASAN}

Karakteristik Perawat Bekerja Di Ruang Rawat Inap Yang Melaksanakan Asuhan Keperawatan

Hasil penelitian ini menunjukkan bahwa jenis kelamin sebagian besar perempuan (73\%). Hasil penelitian ini menemukan tidak adanya perbedaan kemampuan berpikir kritis antara laki-laki dan perempuan. Tidak ada perbedaan yang signifikan kemampuan berpikir kritis berdasarkan jenis kelamin. Jumlah perawat perempuan di Indonesia sampai saat ini masih memegang peranan yang lebih banyak dibandingkan dengan perawat laki-laki. Hal ini disebabkan oleh latar belakang budaya dan kebangsaan serta sejarah keikutsertaan perawat sebagian besar adalah perawat perempuan yang turut serta dalam mengembangkan kesehatan (Priharjo, 2008).

Menurut Suyanto (2008), seorang perawat apabila sudah bekerja melaksanakan asuhan keperawatan kepada pasien selama $\geq 6$ tahun dengan latar pendidikan D3 atau S1 keperawatan maka perawat tersebut sudah bisa menjadi ketua tim dalam kelompoknya, karena sudah memiliki pengalaman dalam melaksanakan asuhan keperawatan.

Faktor Yang Mempengaruhi Penerapan Berpikir Kritis Perawat

Menurut Maslow dalam Siti Mariyam (2006:4) Dalam menjalani kehidupan diperlukan kondisi fisik baik. Kondisi fisik merupakan kebutuhan fisiologi paling dasar bagi kebutuhan manusia. Ketika kondisi fisik seseorang terganggu padahal seseorang tersebut dihadapkan pada situasi yang menuntut pemikiran matang untuk memecahkan 
suatu masalah yang dihadapi, maka kondisi seperti ini sangat dapat mempengaruhi pikirannya, sehingga pemecahan masalah tidak dapat diselesaikan dengan baik.

Dikatakan juga bahwa motivasi dapat mempengaruhi berpikir kritis seseorang. Motivasi merupakan hasil faktor internal dan eksternal. Motivasi adalah upaya yang dilakukan untuk menimbulkan rangsangan, dorongan ataupun pembangkit tenaga seseorang agar mau berbuat sesuatu atau memperlihatkan perilaku tertentu yang telah direncanakan untuk mencapai tujuan yang telah ditetapkan. Dorongan yang kuat dalam bekerja dapat memberikan semangat seseorang untuk berpikir kritis dalam memecahkan masalahnya. Menciptakan minat adalah cara yang sangat baik untuk memberi motivasi pada diri demi mencapai tujuan (Kort 1987, dalam Zafri, 2012).

\section{Hubungan Karakteristik Dengan Penerapan Berpikir Kritis Dalam Melaksanakan Asuhan Keperawatan Asuhan Keperawatan}

Hubungan karakteristik dengan penerapan berpikir kritis perawat dalam melaksanakan asuhan keperawatan tidak ada hubungan antara jenis kelamin, usia, pendidikan, status perkawinan dan status kepegawaian. Sedangkan yang ada hubungan signifikan antara karakteristik dengan penerapan berpikir kritis perawat dalam melaksanakan asuhan keperawatan adalah lama kerja (Yanti Sutriyant,2019)

Menurut Aprisunadi (2011) dalam penelitiannya tidak menemukan adanya hubungan yang bermakna antara usia dan kualitas dalam memberikan asuhan keperawatan. Hasil penelitian ini tidak sejalan dengan hasil penelitian Feng at all (2010) dimana hasil penelitiannya menunjukkan bahwa faktor pengalaman dan usia secara signifikan adalah faktor yang paling mempengaruhi kemampuan seorang perawat dalam memberikan asuhan keperawatan pada pasien.

\section{Proses Hospitalisasi Pasien}

\section{Prasekolah}

Kecemasan yang dialami anak selama dilakukan tindakan keperawatan dipengaruhi oleh kecemasan hospitalisasi, yang terdiri dari tiga fase. Pertama fase protes, ditunjukkan dengan reaksi anak yaitu menangis, 
berteriak, mencari dan memegang erat orang tua, menolak bertemu dan menyerang orang yang tidak dikenal baik secara verbal maupun fisik. Kedua adalah fase putus asa yang ditandai dengan anak tidak begitu aktif, menarik diri dari orang lain, sedih, tidak tertarik terhadap lingkungan, tidak komunikatif, dan menolak makan atau minum. Pada fase ketiga, yaitu fase penerimaan, anak mulai menunjukkan ketertarikan pada lingkungan dan berinteraksi dangkal dengan orang lain atau perawat (Hockenberry \& Wilson, 2013)

Pada hari pertama anak dirawat di rumah sakit, anak berada pada fase pertama yaitu fase protes. Anak masih belum merasa nyaman berada di rumah sakit. Mereka menolak kenyataan bahwa mereka harus berada di rumah sakit dengan menerima berbagai macam terapi. Belum lagi, mereka harus beradaptasi dengan lingkungan, rutinitas, dan orang-orang yang baru. Bukan lagi teman yang ada untuk mengajak bermain, akan tetapi perawat dan tim medis lain yang sering datang mengunjungi mereka dan memberikan berbagai macam prosedur yang membuat stres. Hal ini mengindikasikan bahwa anak belum melewati fase adaptasi untuk mencapai tahap penerimaan, karena tahap penerimaan ini biasanya terjadi setelah anak dirawat di rumah sakit selama beberapa hari atau dalam jangka waktu lebih dari tiga hari dan tiap anak memiliki waktu adaptasi yang berbeda-beda (Hockenberry \& Wilson, 2013).

\section{Berpikir Kritis Terhadap Pasien Prasekolah}

Berpikir kritis dibutuhkan dalam menangani pasien prasekolah, seperti bagaiman cara perawat mengurangi kecemasan pasien dan stress pasien prasekolah, dengan berbagai hal dilakukan, seperti bermain. Begitulah berpikir kritis bekerja, kita dapat menemukan solusi. Pasien prasekolah juga perlu diperhatikan agar dapat mempererat hubungan antara perawat dan pasien.

Contoh permainan yang dilakukan seperti Permainan terapeutik. Permainan terapeutik memiliki beberapa tujuan, yaitu aktivitas pembelajaran, aktivitas pengalihan, dan aktivitas ekspresif. Permainan terapeutik sebagai aktivitas pengalihan atau diversional membantu anak dalam mengalihkan perhatian pada aktivitas 
yang disukainya (Hockenberry \& Wilson, 2013) Mendongeng merupakan salah satu aktivitas yang dapat digunakan dan sesuai dengan perkembangan umur mereka (Andriana, 2011)

Terapi bermain diharapkan dapat menjadi alternative dalam menangani kecemasan anak. Agar anak dapat bermain secara efektif dirumah sakit. Hal ini didukung oleh berbagai penelitian yang dilakukan diantaranya oleh Kaluas I, Ismanto dan Kundre (2015) didapatkan hasil bahwa terapi bermain puzzle dan bercerita juga efektif dalam penurunan kecemasan anak usia prasekolah selama hospitalisasi di ruang anak manado. Jadi berpikir kritis terhadap pasien prasekolah memiliki dampak yang baik untuk meningkat kualitas kesehatan pasien.

\section{KESIMPULAN DAN SARAN}

\section{KESINPULAN}

Dengan berpikir kritis mahasiswa keperawatan memngetahui menangani pasien prasekolah dalam mengurangi kecemasan akibat hospitalisasi contoh dari perlakuan pengurangan kecemasan terhadap pasien prasekolah seperti terapi bermain dan mendongeng,

\section{SARAN}

Akan lebih baik perawat saat melakukan wawancara memberikan sebuah game yang menyenangkan atau menceritakan sebuah dongeng agar pasien tidak merasa gugup ataupun cemas dan memberikan rasa nyaman kepada pasien.

\section{REFERENSI}

Afifah, E. (2005). Hubungan Penerapan Metode Pembelajaran Collaborative Learning (CL) And Problem Based Learning (PBL) Dengan Motivasi Belajar Pada Mahasiswa Keperawatan Universitas Indonesia. Jurnal Keperawatan Indonesia, 9(1).

Fathi, A., \& Simamora, R. H. (2019, March). Investigating nurses' coping strategies in their workplace as an indicator of quality of nurses' life in Indonesia: a preliminary study. In IOP Conference Series: Earth and Environmental Science (Vol. 248, No. 1, p. 012031). IOP Publishing. 
Hidayat, S., \& Nur, L. (2018). Nilai Karakter, Berpikir Kritis dan Psikomotorik Anak Usia Dini. Jurnal Ilmiah Visi,13(1), 29-35.

Huriah, T., Kep, M., \& Kom, S. K. (2018). Metode Student Center Learning: Aplikasi pada Pendidikan Keperawatan. Kencana.

Izzaty, R. E., \& Si, M. (2017). Perilaku Anak Prasekolah. Elex Media Komputindo.

Legi, J. R., Sulaeman, S., \& Purwanti, N. H. (2019). Pengaruh Storytelling dan Guided-Imagery terhadap Tingkat Perubahan Kecemasan Anak Usia Prasekolah yang Dilakukan Tindakan Invasif. Journal of Telenursing (JOTING), 1(1), 145-156.

Marita, R. A. S., Abidin, Z., \& Amanati, S. (2018). Profil Kemampuan Berpikir Kritis Mahasiswa Fisioterapi melalui Self Assessment dan Peer Assessment. Proceeding of The URECOL, 306-312.

Ramadhiani, O. R., \& Siregar, T. (2019). Hubungan Berpikir Kritis dengan Kepedulian (Caring)

Perawat dalam Melaksanakan Asuhan Keperawatan di RSUD Kota Depok. Jurnal Kedokteran dan Kesehatan, 15(2), 148-160.

Rif'at, A., Nurachmah, E., \& Azidin, Y. (2019). Pengalaman Penerapan Kemampuan Berpikir Kritis Perawat Saat Memberikan Asuhan Keperawatan Pada Bayi Berat Lahir Rendah Di RSUD Dr. H. Moch. Ansari Saleh Banjarmasin. DINAMIKA KESEHATAN JURNAL KEBIDANAN $D A N$ KEPERAWATAN, 10(1).।

Saptarini, V. A., Azizah, L. M. R., \& Rahmawati, I. (2019). GAMBARAN CITRA TUBUH PADA MAHASISWA S1 KEPERAWATAN SEMESTER 2 TINGKAT I DI STIKES BINA SEHAT PPNI MOJOKERTO.

Simamora, N. R. H., \& Kep, M. (2009). Buku ajar pendidikan dalam keperawatan. EGC.

Somantri, I. (2016). Efektifitas Terapi Mendongeng terhadap Kecemasan Anak Usia Toddler dan Prasekolah Saat Tindakan 
Keperawatan. Jurnal

Keperawatan Padjadjaran, 4(3).

Sudibjo, N., \& Tondok, L. R. S. (2019).

METODE BOOK TALK

UNTUK MENUMBUHKAN

KETERAMPILAN BERPIKIR

KRITIS DAN KOMUNIKASI

EKSPRESIF VERBAL PADA

$\begin{array}{lll}\text { ANAK USIA } & 3-4\end{array}$

TAHUN. Jurnal

Pendidikan, 20(2), 111-125.

Suryaningsih, N. M. A., Cahaya, I. M.

E., \& Poerwati, C. E. (2016).
Implementasi Pembelajaran

Inkuiri Terbimbing Berbasis

Permainan Dalam Meningkatkan

Kreativitas Anak Usia Dini. JPI

(Jurnal

Pendidikan

Indonesia), 5(2), 212-220.

Sutriyanti, Y., \& Mulyadi, M. (2019).

Analisis Faktor-Faktor yang Mempengaruhi Penerapan

Berpikir Kritis Perawat dalam Melaksanakan Asuhan

Keperawatan di Rumah Sakit. JURNAL KEPERAWATAN RAFLESIA, 1(1), 21-32. 